NATALIA ŻochOWSKA

Uniwersytet Mikołaja Kopernika Instytut Języka Polskiego

\title{
Mimo woli i mimowolnie jako wykładniki relacji umysł-ciało
}

Słowa klucze: łączliwość leksykalna; przysłówek; umysł; ciało

Keywords: lexical collocation; adverb; mind; body

Przedmiotem niniejszego artykułu jest jednostka mimowolnie, której cechy semantyczne będę porównywać z właściwościami przysłówków mimo woli i odruchowo. Celem analizy jest przede wszystkim pokazanie, dlaczego jednostek mimowolnie i mimo woli nie należy uznawać za wyrażenia synonimiczne.

Jednym z argumentów przemawiających za nierównoznacznością badanych przysłówków może być fakt, że nie we wszystkich kontekstach jednostkę mimo woli można zastąpić wyrażeniem mimowolnie. Ilustrują to następujące zdania:

(1) Timur Szah, przenoszac stolice do Kabulu, mimo woli przyczynit sie do upadku pasztuńskiej oazy.

(2) ?Timur Szah, przenoszac stolice do Kabulu, mimowolnie przyczynit się do upadku pasztuńskiej oazy.

(3) Uczestnik szarpnat się pokazują mimo woli jakość mocowań. 
(4) ?Uczestnik szarpnąt się pokazując mimowolnie jakość mocowań.

(5) Żolnierze poprowadzili go przez most Tryumfalny, jakby mimo woli dajac jego tryumfowi świadectwo.

(6) ?Żotnierze poprowadzili go przez most Tryumfalny, jakby mimowolnie dajac jego tryumfowi świadectwo.

(7) Nie miałam fajki w ustach, a jestem chora od papierosów wypalonych mimo woli.

(8) ?Nie miałam fajki w ustach, a jestem chora od papierosów wypalonych mimowolnie.

(9) Kamienicznik mimo woli - tak siebie nazywa pan Stanisław.

(10) *Kamienicznik mimowolnie - tak siebie nazywa pan Stanistaw.

(11) Przecież my wszyscy mimo woli jesteśmy udziałowcami w przedsiębiorstwie Polska z o.o.

(12) *Przecież my wszyscy mimowolnie jesteśmy udziałowcami w przedsiębiorstwie Polska z o.o.

Do wyjaśnienia, dlaczego zdania (2), (4), (6) i (8) uznałam za nieakceptowalne, wykorzystam ideę rozróżnienia perspektywy, z jakiej wypowiadane jest zdanie - chodzi o perspektywę obiektywną i subiektywną. Rozróżnienie to stosowane jest przez I. Duraj-Nowosielską, według której perspektywa subiektywna to ,perspektywa podmiotu zdania, zakładająca odpowiednią intencję podmiotu odniesioną do danego w zdaniu obiektu" (Duraj-Nowosielska 2007: 216). Perspektywa obiektywna natomiast to „podstawowa perspektywa nadawcza: nadawca wychodzi tutaj od jakiegoś ,zdarzenia skutkowego" rzeczywistego (aspekt dokonany) lub przewidywanego na podstawie obiektywnych danych" (Duraj-Nowosielska 2007: 216).

Osoby, o których mowa w zdaniach (1)-(12), nie wykonały czynności wyrażonych występującymi tam czasownikami - zrobiły coś, co sprawiło, że stało się coś innego, np. ktoś „,szarpnął się” (poruszył się w gwałtowny sposób), co sprawiło, że pokazał jakość mocowań, ktoś przeniósł stolicę do Kabulu, co przyczyniło się do upadku pasztuńskiej oazy itd. To, co zrobiły osoby w zdaniach (1)-(12) opisywane jest z perspektywy obiektywnej, a więc z punktu widzenia obserwatora, a nie działającego - dlatego brane są pod uwagę skutki robienia, a nie samo robienie. Osoby, o których mowa w tych zdaniach, zrobiły coś, ale tylko z perspektywy nadawcy - dokładniej mówiąc, spowodowały coś, nie zamierzając tego powodować, nie wykonały czynności, o której 
mowa. Jednostka mimowolnie implikuje natomiast pojęcie czynności wyrażone czasownikiem (o czym będzie jeszcze mowa) i to właśnie sprawia, że przykłady (2), (4), (6) i (8) są niemożliwe do zaakceptowania.

Przykłady (10) i (12) również nie dotyczą robienia - mowa jest w nich o sytuacji, w jakiej ktoś się znalazł (z jakiegoś powodu), dlatego obecność przysłówka mimowolnie powoduje dewiację tych zdań.

$\mathrm{Na}$ podstawie analizy prezentowanej w innej pracy (Żochowska 2013a) udało mi się ustalić, że gdy określamy jakąś czynność jednostką mimo woli, mówimy, że czynność ta została wykonana bez wcześniejszego dokonania wyboru. Wybór ten (gdyby go dokonywano) byłby wyborem między rozpoczęciem czynności $p$ a jej nierozpoczynaniem. Jeżeli mówimy, że $x$ mimo woli zrobił $p$, to mówimy, że nie dokonał wyboru, że zrobi $p$ (zamiast nie zrobić $p$ ), czyli nie myślał o alternatywie - o tym, że może nie robić $p$ i nie było, ani tak, że chciał zrobić $p$, ani tak, że nie chciał zrobić $p$.

Wydaje się to tłumaczyć fakt, że przysłówek mimo woli - podobnie jak analizowany przez Duraj-Nowosielską przysłówek niechcacy (Duraj-Nowosielska 2012) - występuje w zdaniach, w których o czynności (przez niego określanej) mówi się z perspektywy obiektywnej.

Natomiast zdania (2), (4), (6), (8), (10) i (12) pokazują, że o czynnościach wykonanych mimowolnie nie mówi się z perspektywy obiektywnej. Co ciekawe, wyrażenie mimowolnie nie może tworzyć poprawnych semantycznie konstrukcji ani z jednostkami konstytuowanymi przez czasowniki kauzatywne (co jest oczywiste), ani z predykatami kauzatywno-obiektywnymi:

1 Podział na trzy wymienione rodzaje jednostek stosuję za Duraj-Nowosielską (2007 i 2012). Chodzi o: a) jednostki ,subiektywno-agentywne”, czyli predykaty z podmiotem osobowym (np. [ktoś] budzi [kogoś], [ktośs zachęca [kogoś] do [czegoś]). Cechą tych predykatów jest to, że ,ujmują one sytuację z punktu widzenia podmiotu: zakładają odpowiednią intencję podmiotu, nie zakładają natomiast, że działania przez niego podjęte [...] dały jakikolwiek skutek w rzeczywistości" (Duraj-Nowosielska 2012: 25); b) jednostki kauzatywne z podmiotem nieprzedmiotowym (np. [coś] [kogoś'] budzi, [coś] [kogoś] zachęca do [czegoś] ), które ,zbudowane są wokół podstawowego predykatu kauzatywnego [coś] spowodowało/powoduje [coś] i nie zakładają w ogóle, że na argument „kauzujący” będzie się składało działanie podmiotu [...]. Nawet jeśli w skład tego argumentu wchodzi jakieś działanie podmiotu, nie ma mowy o odpowiedniej intencji - całość sytuacji jest ujmowana z punktu widzenia obiektywnych skutków w rzeczywistości (Duraj-Nowosielska 2012: 26)”, i c) jednostki „kauzatywno-agentywne” (,obiektywno-agentywne"); które - zdaniem autorki Robić coś i coś powodować - mają postać [kogoś] [ktoś] obudził/budzi przez [coś, co zrobit, robi] i są zawsze derywowane od jednostek 
(13) Piotr mimo woli zranit siostre swoim zachowaniem.

(14) *Piotr mimowolnie zranit siostrę swoim zachowaniem.

(15) Swoim narzekaniem Anna mimo woli zachęciła Stacha do wyjazdu.

(16) *Swoim narzekaniem Anna mimowolnie zachęciła Stacha do wyjazdu.

Zakres czasowników, z którymi przysłówek mimowolnie tworzy konstrukcje poprawne jest bardzo ograniczony. Przede wszystkim, podobnie jak jednostka odruchowo ${ }^{2}$, nie może tworzyć on konstrukcji z czasownikami wyrażającymi czynności, których rozpoczęcie i zakończenie są oddalone w czasie, por:

(17) *Prozaik odruchowo napisat kryminat.

(18) *Prozaik mimowolnie napisat kryminat.

Jednak przysłówek mimowolnie nakłada na czasownik jeszcze dodatkowe ograniczenia - czynność określana przez badaną jednostkę nie może być czynnością złożoną, por::

(19) Niektórzy mówia, że zamykanie tych drzwi jest bardzo skomplikowane, ale ja zamykam je odruchowo.

(20) *Niektórzy mówiq, że zamykanie tych drzwi jest bardzo skomplikowane, ale ja zamykam je mimowolnie.

(21) Marek wszedt do przedpokoju i odruchowo zawiqzał buty.

(22) *Marek wszedt do pokoju i mimowolnie zawiqzał buty.

Należy również zwrócić uwagę, że chociaż jednostka mimowolnie tworzy poprawne semantycznie konstrukcje z czasownikami związanymi z percepcją wzrokową, co pokazują przykłady (23) i (24), wykluczone są zdania, w których współwystępowałaby z czasownikiem percepcyjnym informującym, że podmiot zdarzenia jest eksperienserem, czyli tylko doświadcza ${ }^{3}$

kauzatywnych, po których „dziedziczą implikację kauzatywną, co oznacza, że nadawca ujmuje opisywaną przez siebie sytuację z obiektywnego punktu widzenia (odnotowawszy uprzednio określone skutki w rzeczywistości)" (Duraj-Nowosielska 2012: 26).

2 O tej jednostce pisałam w innym miejscu: Żochowska 2013 b.

${ }^{3} \mathrm{Na}$ taki bierny charakter czynności wyrażanych czasownikami ktoś zobaczył coś i ktoś usłyszat coś wskazują choćby eksplikacje semantyczne tych jednostek zapropono- 
pewnych stanów rzeczy (25)-(28), a także zdania, w których mimowolnie współwystępuje z predykatami wyrażającymi czynności związane z percepcją i zawierającymi jednocześnie $w$ znaczeniu informację o tym, że dana czynność była zamierzona, jak w przykładach (29)-(30), por.:

(23) Chowajac dokumenty, spojrzatem mimowolnie na fronton Ambasady.

(24) Kazurek mimowolnie zerkną na sqsiadkę.

(25) *Wtedy brat mimowolnie zobaczyt jej nagi pośladek.

(26) Wtedy brat mimo woli zobaczyt jej nagi pośladek.

(27) *Kusa siedziała w poczekalni i mimowolnie ustyszała diagnozę koleżanki.

(28) Kusa siedziała $w$ poczekalni i mimo woli ustyszała diagnozę koleżanki.

(29) *Wtadek przyjrzat się mimowolnie nowej cioci.

(30) *Sąsiad z piętra wyżej podstuchał mimowolnie rozmowę kochanków.

Zdania (26) i (28) są poprawne, ponieważ mówi się w nich o skutku - to, że ktoś coś zobaczył czy usłyszał, jest skutkiem tego, że np. znalazł się w danym miejscu. Jednostka mimo woli, jak już to zostało powiedziane, w przeciwieństwie do przysłówka mimowolnie, odnosi się bardzo często do skutków czynności czy stanu (choć mówi też o tym, co było przed ich rozpoczęciem Żochowska 2013a), a nie do nich samych. Natomiast wyrażenie mimowolnie implikuje pojęcie czynności. Dlatego nieakceptowalne są zdania (25) i (27).

wane przez A. Dobaczewskiego: „ktoś ${ }_{\mathrm{i}}$ zobaczyt $\operatorname{coss}_{\mathrm{r}}$ gdzieś ${ }_{\mathrm{v}}$ i S. Żurowskiego „[ktośs] ustyszat [cośr]", por.:

'(a) $\operatorname{coś}_{\varphi}, \operatorname{co}_{\varphi}$ d ziało si ę [podkr. N. Ż.] w czyichś ${ }_{i}$ oczach i jest takie, że

(a') $\operatorname{coś}_{\varphi}$ może dziać się w czyichś ${ }_{\beta}$ oczach z tego powodu, że rzeczy takie jak cośr są przed czyimiśs ${ }_{\beta}$ oczami

(a") nieprawda, że coś ${ }_{\varphi}$ może dziać się w innej części czyjegoś ${ }_{u}$ ciała,

(b) spowodowało, że ktoś $_{\mathrm{i}}$ może (mógł) wiedzieć coś x $_{\mathrm{X}}$ o czymśs"” (Dobaczewski 2002: 60)

'(a) $\operatorname{coś}_{\varphi}, \operatorname{co}_{\varphi}$ d ziało się [podkr. N. Ż.] w czyichś ${ }_{i}$ uszach i jest takie, że

(a') nieprawda, że coś ${ }_{\varphi}$ może dziać się w innej części czyjegośs ciała i

(a') coś jest takie, że może powodować, że $\operatorname{coś}_{\varphi}$ dzieje się w czyichś ${ }_{\beta}$ uszach,

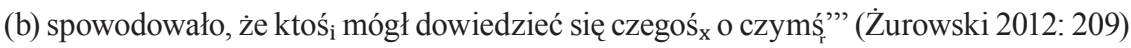


Zdania z jednostką mimowolnie pokazują, że przysłówek ten tworzy poprawne zdania z czasownikami wyrażającymi czynności, które wykonuje się własnym ciałem, „w obrębie” własnego ciała, bez użycia narzędzia (takiego, które nie jest własnym ciałem ${ }^{4}$, czyli nie jest quasi-narzędziem) i bez udziału innej osoby. Za przykład niech posłużą następujące zdania:

(31) Szczupła sylwetka najpierw zastygła, jakby zaskoczona, a potem zaczęła mimowolnie gestykulować wolnym ramieniem.

(32) Wizja Vasariego jest tak dosłowna, że patrzqc na wiszacych głowami $w$ dót nieszczęśników, ścisnałem mimowolnie pośladki opięte biatymi levisami.

(33) Patrzę na Marka, na jego świdrujace oczka strzelajace spod ciemnej grzywki i mimowolnie uśmiecham się, bo przecież sporo piw mamy za soba.

(34) Renatka posyła mi branżowy uśmiech, sugerujacy sypialniane zwiazki między nami; na myśl o tym moja twarz mimowolnie wygięła się w szyderczo-melancholijnym grymasie.

Dzięki analizie prezentowanej w innej pracy (Żochowska 2013b) udało mi się ustalić, że przysłówek odruchowo określa krótkotrwałą czynność, którą wykonuje się bez myślenia o niej. Odruchowo można np. wyciągnąć szyję, cofnąć się, zamknąć drzwi, otworzyć okno. Przywołane wcześniej zdania (19)-(22) pokazują, że nie wszystko, co można zrobić odruchowo, można zrobić mimowolnie. Mimowolnie nie można wykonać czynności złożonych, takich jak np. wiązanie buta. Wydaje się jednak, że badana w niniejszym artykule jednostka nakłada ograniczenia również na czasowniki wyrażające czynności niezłożone, takie jak np. dotknięcie czyjegoś ramienia czy ugryzienie jabłka, por::

(35) ?Jacek mimowolnie złapat Basię za włosy.

(36) Jacek odruchowo złapat Basię za włosy.

(37) *Anka wtedy mimowolnie ugryzła jabtko.

(38) Anka wtedy odruchowo ugryzła jabtko.

${ }^{4}$ Według M. Grochowskiego „narzędziem (...) jest przedmiot materialny martwy o ustalonych konturach i część ciała istoty żywej”, np.: Jan czesze się szczotką, Babcia cedzi zioła przez sitko, Piotr dłubie palcem w uchu, Wojtek tnie nitkę zębami (Grochowski 1975: 107-122). 
(39) *Tata mimowolnie podrapat Reksia po uchu.

(40) Tata odruchowo podrapat Reksia po uchu.

Co ciekawe, poprawne są zdania, takie jak:

(41) Jacek mimowolnie złapat się za włosy.

(42) Anka mimowolnie zagryzła wargi.

(43) Tata mimowolnie podrapat się po uchu.

Ograniczenia, jakie jednostka mimowolnie nakłada na występujące w jej sąsiedztwie czasowniki, wskazują, że określa ona to, co ktoś robi z własnym ciałem. To z kolei może oznaczać, że implikuje ona pojęcie ciała agensa, a relacja semantyczna zachodząca między przysłówkami mimo woli i mimowolnie odzwierciedla relację zauważoną przez A. Wierzbicką w pracy z 1969 roku. Autorka Dociekań semantycznych zwraca uwagę na nieidentyczność podmiotów, o których orzeka się w zdaniach, takich jak Adam waży $70 \mathrm{~kg}$. i Adam jest dobry. (Wierzbicka 1969: 62, 63). Wierzbicka stwierdza:

predykaty fizyczne i psychiczne mogą być dołączone do tego samego podmiotu tylko w strukturze powierzchniowej; w strukturze głębokiej predykaty fizyczne i psychiczne nigdy nie współwystępują przy tych samych podmiotach (Wierzbicka 1969: 64, 65).

W terminologii Wierzbickiej przysłówek mimowolnie byłby więc predykatem fizycznym, który nie może tworzyć konstrukcji z predykatami psychicznymi (co ilustrują np. zdania (14) i (16)), natomiast mimo woli należałoby uznać za wyrażenie, które może współwystępować zarówno z predykatami fizycznymi, jak i psychicznymi. Pokazują to chociażby następujące przykłady:

(44) Piotr mówiqc to mimo woli zranit Annę.

(45) Piotr widzqc ten obraz mimo woli zacisną pośladki.

O opozycji, jaką mam na myśli, pisze też Wittgenstein:

Zdaje się paradoksem, że w jednej relacji mieszamy ze sobą stany ciała i stany świadomości: Cierpiat straszne męki i rzucat się niespokojnie. Jest to całkiem zwyczajne powiedzenie; czemu więc zdaje się nam paradoksalne? Bo chcemy rzec, iż zdanie to dotyczy czegoś uchwytnego i czegoś nieuchwytnego (Wittgenstein 2004: 180). 
Ograniczenia łączliwości leksykalnej przysłówka mimowolnie potwierdzaja postawioną w tym artykule hipotezę, mówiąca, że wyrażenie to w przeciwieństwie do jednostki mimo woli - współwystępuje tylko z predykatami „fizycznymi”. Wierzbicka w przywoływanej pracy konstatuje:

Takie czasowniki jak usiasść, wyciagnać się, uklęknać itp. są semantycznie nie mniej „przechodnie” niż posadzić, położyć, niesśc itp. [...] Wszystkie te pozornie nieprzechodnie czasowniki (usiaśśc, uklęknqć itp.) po prostu zawierają już obiekt w swym znaczeniu, a obiekt ten jest jednoznacznie wyznaczony: własne ciało (Wierzbicka 1969: 76).

Wydaje się, że z takim jednoznacznie wyznaczonym obiektem (w postaci własnego ciała, tj. ciała agensa) mamy do czynienia również w wypadku przysłówka mimowolnie. Dlatego często tworzy on konstrukcje właśnie z tymi z czasownikami, o których pisała Wierzbicka:

(46) Przed kościołem święty Józef rozkładat zmęczone ręce; Zygmunt przeżegnat się mimowolnie.

(47) Co to? - zapytał Tomek prędko, odsuwajac się mimowolnie, bo Bum-Bum nachylit się nad nim.

Trudne do zaakceptowania są natomiast zdania, w których przysłówek mimowolnie pojawia się obok czasowników implikujących użycie narzędzia innego niż ciało, por:

(48) ?Janek mimowolnie przecią kartkę (za pomocq nożyczek).

(49) ?Zuza mimowolnie nabazgrała coś w zeszycie (długopisem).

Wynika z tego, że przysłówek mimowolnie mówi o ciele agensa, że je implikuje - daje to odpowiedź na pytanie o cechę odróżniająca go od jednostki mimo woli.

Wierzbicka pisze:

ciało ludzkie jest jedyną rzeczą (obiektem fizycznym) w świecie, którego stany mogą być wywoływane bezpośrednio wolą osoby [...] można sądzić, że zależność stanów ludzkiego ciała od woli człowieka ma zasadnicze znacze- 


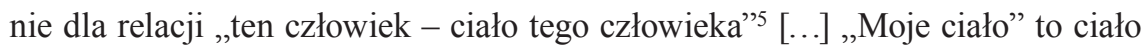
(rzecz), która ,,jest do mojej dyspozycji” (z którą mogę robić, co chcę) (Wierzbicka 1969: 72 i 76, 77).

Opisana wyżej cecha wyrażenia mimowolnie wyjaśniałaby, dlaczego nie może ono współtworzyć (jako określenie podstawowego czasownika) zdań wypowiadanych z perspektywy obiektywnej, tj. takich, w których mówi się o skutkach działania, robienia. Mimowolnie zakłada bowiem właśnie aktualne (bo „zaktualizowane” w ciele) robienie - dlatego nieakceptowalne sa przytoczone na początku rozważań zdania (2), (4), (6), (8), (10) i (12).

Jak już pokazałam na przykładzie zdań (29) i (30), mimowolnie nie może tworzyć poprawnych semantycznie konstrukcji z czasownikami, które implikują wolę robiącego. Z kolei przykłady (25)-(27) świadczą o tym, że niemożliwe jest również określenie badanym przysłówkiem czynności/stanów, które nie są powodowane wolą robiącego (nie powiemy np. *Mimowolnie poczułam dreszcz. czy *Przejęzyczyłam się mimowolnie.). Mimowolnie może zatem współwystępować z czasownikami wyrażającymi czynności (dotyczące ciała agensa), które mogą być powodowane wolą, ale można je też wykonywać bez udziału woli. Badania nad łączliwością leksykalną jednostki mimo woli pomogły mi ustalić, że mówi ona o niedokonaniu przez agensa wyboru co do rozpoczęcia danej czynności. Z kolei analiza dotycząca przysłówka odruchowo wykazała, że w jego znaczeniu zawarty jest komponent 'nie było tak, że (x) chciał' (Żochowska 2013a i 2013b), a także informacja, że agens 'nie myśli o c z y n n o ś c i', nie zaś, że 'nie myśli o tym, że ją wykonuje'. Znaczyłoby to, że jeżeli ktoś robi coś odruchowo, to 'nie myśli o p', a nie - 'nie myśli o tym, że robi p'. Przysłówek odruchowo dotyczy więc czynności i nie należy go łączyć z samoświadomością czy introspekcją, których istnienie podważał Gilbert Ryle (Ryle 1970) ${ }^{6}$, ponieważ mówi o stosunku agensa do czynności, a nie do siebie jako wykonawcy. Natomiast jednostka mimowolnie mówi o stosunku agensa do swojego ciała wykonującego daną czynność, a więc

5 Wierzbicka przywołuje w swojej pracy ideę Platona dotyczącą człowieka jako użytkownika swojego ciała, wyrażoną w Alcybiadesie (Platon 2002).

${ }^{6}$ Ryle polemizował z twierdzeniem mówiącym, ,(1) że umysł nie potrafi nie być ciągle świadomym tych wszystkich zjawisk mających rozgrywać się na jego wewnętrznej scenie oraz, że (2) może on nadto z rozmysłem analizować, dzięki jakiemuś rodzajowi niezmysłowych spostrzeżeń, przynajmniej niektóre spośród swych stanów i czynności” (Ryle 1970: 253, 254). 
właśnie do tego '̇̇ e (swoim ciałem) ro b i $p$ '. Stan opisywany przez to wyrażenie przywodzi na myśl sytuację (opisywaną przez Sartre’a i analizowaną m. in. przez M. Drwięgę: Sartre 2007 i Drwięga 2005; 125-128), gdy ból jest ciałem. Według Sartre'a stan taki ma miejsce, gdy mamy do czynienia ze świadomością nierefleksyjną ${ }^{7}$ tóra - w interpretacji M. Drwięgi

jest zwrócona ku światu, nie ma w niej ego, np. czytam książkę i pole mojej świadomości jest wypełnione treścią tej książki. (...) Gdy przerywam czytanie i próbuje „uchwycić mój ból”, to skierowuję refleksję na obecną, przeżywaną przeze mnie świadomość bólu. Wówczas przeżycie bólu przekształca się w ból-przedmiot, staje się czymś psychicznym. Ten psychiczny przedmiot ujmowany poprzez ból staje się cierpieniem. Dla świadomości nierefleksyjnej ból był ciałem, było to coś odczuwalnego, z kolei dla świadomości refleksyjnej cierpienie jest czymś różnym od ciała, posiada bowiem swoją własną formę. Na poziomie refleksyjnym ciało nie jest bezpośrednio i tematycznie dane dla świadomości (Drwięga 2005: 125-128).

Wydaje się, że przysłówek mimowolnie określa właśnie takie sytuacje, w których mamy do czynienia ze „świadomością nierefleksyjną”, czyli sytuacje, gdy czynność ,jest ciałem"- nie jest więc nazwana (nie jest wyodrębniona z reszty świata), tylko w y k o n y w a n a, co w języku Sartre'a odpowiada sytuacji odczuwania bólu. Jeżeli robimy coś mimowolnie, nie zastanawiamy się nad tym robieniem, nie myślimy o nim - wykonywana czynność nie jest nazwana i dana świadomości, jest to czynność „bezrefleksyjna” (co odpowiada „świadomości nierefleksyjnej” u Sartre’a), będąca niejako częścią nas. Czynność taką można porównać do oddychania czy mrugania. Nie znaczy to oczywiście, że każdą czynność mrugania i oddychania można określić jednostką mimowolnie (o łączliwości mimowolnie z czasownikami wyrażającymi czynności niezależne od woli człowieka była mowa wcześniej).

Czynności „bezrefleksyjne” (też tylko niektóre) można określić także przysłówkiem mimo woli, jednak to wyrażenie służyć może również do opisywania skutków działania agensa, do określania tego, co agens spowodował (nie tylko swoim ciałem). Na tym właśnie polega różnica miedzy znaczeniem porównywanych jednostek - prezentowana analiza pokazuje, że wyrażenie

7 Którą Sartre odróżnia od świadomości refleksyjnej (Sartre 2007). 
mimowolnie mówi o ciele agensa. Przysłówek mimo woli dotyczy po prostu agensa, może więc określać zarówno jego stosunek do czynności, jak i do ciała - pokazują to zdania (44) i (45).

Struktura znaczeniowa jednostki mimowolnie jest zatem bardziej złożona od struktury wyrażenia mimo woli, dlatego liczba czasowników, z którymi przysłówek mimowolnie tworzy konstrukcje semantycznie poprawne, jest znacznie mniejsza.

\section{Bibliografia}

Dobaczewski A., 2002, Zjawiska percepcji wzrokowej: studium semantyczne, Warszawa: Katedra Lingwistyki Formalnej Uniwersytetu Warszawskiego.

Drwięga M., 2005, Ciało człowieka. Studium z antropologii filozoficznej, Kraków: Księgarnia Akademicka.

Duraj-Nowosielska I., 2007, Robić coś i coś powodować, Warszawa: Wydział Polonistyki Uniwersytetu Warszawskiego.

Duraj-Nowosielska I., 2012, Nie przypadkiem o niechcacy, Warszawa: Wydawnictwo Uniwersytetu Kardynała Stefana Wyszyńskiego.

Grochowsкi M., 1975, Środek czynności w strukturze zdania, Wrocław: Zakład Narodowy im. Ossolińskich.

Platon, 2002, Uczta, przekł. i wstęp W. Witwicki, Kęty: Antyk.

Ryle G., 1970, Czym jest umyst?, przekł. W. Marciszewski, Warszawa: Państwowe Wydawnictwo Naukowe.

SARtre J.-P., 2007, Byt i nicość: zarys ontologii fenomenologicznej, przekł. J. Kiełbasa, Kraków: Wydawnictwo Zielona Sowa.

WierzBicka A., 1969, Dociekania semantyczne, Wrocław: Zakład Narodowy im. Ossolińskich.

Wittgenstein L., 2004, Dociekania filozoficzne, przekł. B. Wolniewicz, Warszawa: Wydawnictwo Naukowe PWN.

Żochowska N., 2013a, Charakterystyka semantyczna wyrażeń chcqc nie chcqc i mimo woli, Linguistica Copernicana 1(9)/ 2013, s. 143-163.

Żochowska N., 2013b, Charakterystyka semantyczna jednostki odruchowo na tle innych przysłówków dotyczących myślenia, woli i świadomości, Poradnik Językowy 9, s. 57-66.

ŻURowsKi S., 2012, Wyrażenia percepcji stuchowej w języku polskim, Toruń: Wydawnictwo Naukowe Uniwersytetu Mikołaja Kopernika. 


\section{Mimo woli and mimowolnie as the Exponents of Relation 'mind-body' ( s u m m a r y )}

The subject matter of this article is the adverb mimowolnie, which I compare with such expressions as mimo woli and odruchowo. However the aim of the discussion is to establish the semantic difference between these adverbs.

In the article, I attempt to justify the hypothesis that the semantic relation between them is similar to the one noticed by A. Wierzbicka, in her work from 1969, where she emphasizes the non-identicality of subjects in such sentences as Adam waży $70 \mathrm{~kg}$. and Adam jest dobry. (Wierzbicka 1969: 62, 63). In order to prove the hypothesis proposed, I demonstrate the semantic restrictions imposed by the lexical unit mimowolnie on verbs (e.g. perceptual verbs), and then I try to explain what they stem from.

At the end of the article, I put forward the thesis that the adverb mimowolnie contains, in its semantic structure, an explicitly specified object of activity, which is one's own body and that it designates the agent's attitude towards his or her body that is performing the given activity. 